\title{
Retrofitting of Beams Using Externally Bonded Glass Fiber Reinforced Polymer (GFRP) Wraps
}

\author{
Amol Suresh Satpute ${ }^{1}$, Dr. Mahavir Balmukund Varma ${ }^{2}$ \\ ${ }^{I}$ (Assistant Professor, Department of Civil Engineering, Maharashtra Institute of Technology, Aurangabad, \\ Maharashtra, India) \\ ${ }^{2}$ (Associate Professor, Department of Applied Mechanics, Government College of Engineering, Aurangabad, \\ Maharashtra, India)
}

\begin{abstract}
The research work related to retrofitting of building and civil structural elements had been done by many engineers. It is an essential medicine required to be applied for enhancing the structural health of a structural element over a serviceability period of life. In general a beam or slab needs to carry an additional load as the purpose of occupancy has been changed over a period of time for a specified area in a building and it needs to be replaced for a very short difference in its load carrying capacity; in such case the application of the externally bonded Glass Fibre Reinforced Polymer (GFRP) wraps can be a remedy or solution over the problem. In present study a detailed investigation on the concrete beam specimens $(5.90 \mathrm{in}$. [150 mm] width $\times$ $5.90 \mathrm{in} .[150 \mathrm{~mm}]$ depth $\times 27.56 \mathrm{in} .[700 \mathrm{~mm}]$ length) made with different steel reinforcement configuration and strengthened with glass fiber reinforced polymer (GFRP) wraps in single, double and triple layer was carried out after 28 days of water curing. The Glass Fiber Reinforced Polymer can be used in various patterns i.e. related to orientations of the fibers, shape of the wrapping and locations of the wrappings to make effective use of the materials and ensure the desired purpose of imparting long service life of the selected technique. One of these new and advanced techniques is the externally bonded GFRP wraps, which consists of wrapping the concrete beams externally with the help of a resin matrix. The purpose of this study is to retrofit the beam to enhance the load carrying capacity. The beam specimens were tested under four point load test to find out the ultimate load and deflection in the member. From the observations, a considerable increase in load carrying capacity was recorded.
\end{abstract}

Keywords: cracking pattern, externally bonded, glass fiber reinforced polymer, retrofitting, shear capacity, strengthening, ultimate deflection, ultimate load

\section{Introduction}

Fiber reinforced polymer (FRP) is a composite material consisting fibers in a polymeric/ resin matrix. Fiber reinforced polymer (FRP) composite is a composition of two or more materials. The wide utilization of FRP is increasing significantly in recent years, both for strengthening of existing structures and for new constructions. One of the challenges in strengthening of concrete structures is selection of a strengthening method that will enhance the strength and serviceability of the structure while addressing limitations such as constructability, building operations, and budget. The other substitute available for retrofitting is, Near Surface Mounted (NSM) Glass fiber reinforced polymer reinforcing technique in the form of bars and strips is practical, significantly improves the stiffness, and increases the flexural capacity of reinforced concrete beams [1].

Structural strengthening is required in the following situations:

1. Additional strength may be required to allow for higher loads to be placed on the structure. This condition may arise very often when the changes are made in the occupancy conditions and a higher load carrying capacity of the structural member is required to suffice the enhanced counteracting loads. This condition may also arise if additional mechanical equipment's, filing systems, planters, or other items are being added to a structure.

2. A structure needs strengthening to allow itself to resist loads such as additional floor loads, wind loads, seismic loads and blast loads etc. \& that were not considered in the original structural design.

3. Additional strength may be needed due to deficiency in the structure's ability to carry the original design loads. Deficiencies may be the result of deterioration (e.g., corrosion of steel reinforcement and loss of concrete section), structural damage (e.g., vehicular impact, excessive wear, excessive loading, and fire), or errors in the original design or construction.

The majority of structural strengthening involves the improvement in the ability of the structural element to safely resist one or more of the internal forces caused by loading i.e. shear force and axial force. Strengthening is accomplished by increasing the capacity of member to resist the magnitude of these forces. The retrofitting will be used as a cost-effective solution to the replacement of these structures and is commonly the sole feasible option. Glass Fiber reinforced Polymers (GFRP) wrap is well suited to the current application 
as a result of their high strength-to-weight ratio, good fatigue properties and wonderful resistance to corrosion [2].The results of experimental study undertaken indicated that, significant increases in the shear strength and improvements in the overall structural behavior of beams with insufficient shear capacity could be achieved by proper application of GFRP wraps [3]. The application of FRP poses minimal modification to the geometry, aesthetics and utility of the structure [4]. The studies related to the enhancement of shear capacity had been made and published in various international journals. The pattern of application of the externally bonded GFRP varies in the studies undertaken. This study attempts to find out the extent of improvement in the shear performance of the reinforced concrete beam and studies the mode of failure when strengthened with externally bonded GFRP wraps.

\section{Research Significance}

The retrofitting stands to be an easy and cheap as the expenses supposed to be incurred in case of replacing the structure as a whole. The studies on enhancement of shear capacity of beams using externally bonded technique have been made and reported. But, still many more to be undertaken for studies with regards to shape, location and forms of GFRP. The authors believe that this detail study dealing with the enhancement of shear capacity or load bearing capacity of reinforced concrete beam using externally bonded technique with a new material from the GFRP family (Non Crimp Fabric/Fiber) is carried out for the first time and will be very useful to concrete technology.

\section{Experimental Investigation}

Total six numbers of concrete cube specimens were cast of size $(5.90 \mathrm{in}$. [150 mm] width $\times 5.90 \mathrm{in}$. [150 mm] depth $\times 5.90$ in. [150 mm] length) for the determination of compressive strength of concrete for design mix of grade M20. Then the six numbers of beam specimens using same concrete were cast of size (5.90 in. $[150 \mathrm{~mm}]$ width $\times 5.90 \mathrm{in}$. [150 mm] depth $\times 27.56$ in. [700 mm] length). The three types of beams were cast. First type was a single number of plain concrete beam; second type includes four number of beams provided with bottom (tension) reinforcement of 2 numbers of $10 \mathrm{~mm}$ diameter HYSD bars only and the third type includes a single number of beam provided with top, bottom reinforcement of 2 numbers of $10 \mathrm{~mm}$ diameter HYSD bars each and a shear reinforcement of $8 \mathrm{~mm}$ diameter HYSD bars at a distance of $155 \mathrm{~mm}$ center to center. Then the other variable includes the strengthening of three numbers of second type of beams externally bonded with glass fiber reinforced polymer (GFRP) wraps in single, double and triple layer each respectively. The details of the beams are given in the Table $\mathbf{1}$ and a diagrammatic sketch of the unstrengthened (control beams) and strengthened beams is shown in the Fig. 1 and Fig. 2 respectively.

Table 1 - Details of Beam Specimens

\begin{tabular}{|l|l|l|l|l|l|l|}
\hline $\begin{array}{l}\text { Sr. } \\
\text { No }\end{array}$ & Beam Id & Nos. & Reinforcement Configuration & \multicolumn{2}{l|}{ Beam Reinforcement } & Stirrups \\
\cline { 5 - 7 }$\cdot$ & & & & At Top & At Bottom & \\
\hline 1 & PC & 1 & Plain Beam & --- & --- & --- \\
\hline 2 & BL & 1 & Only with bottom reinforcement & --- & $2-10 \#$ & --- \\
\hline 3 & SL & 1 & With bottom, top and shear reinf. & $2-10 \#$ & $2-10 \#$ & $8 \#$ @ $150 \mathrm{~mm} \mathrm{C/C}$ \\
\hline 4 & BLSW & 1 & Only with bottom reinforcement & --- & $2-10 \#$ & --- \\
\hline 5 & BLDW & 1 & Only with bottom reinforcement & --- & $2-10 \#$ & --- \\
\hline 6 & BLTW & 1 & Only with bottom reinforcement & --- & $2-10 \#$ & --- \\
\hline
\end{tabular}
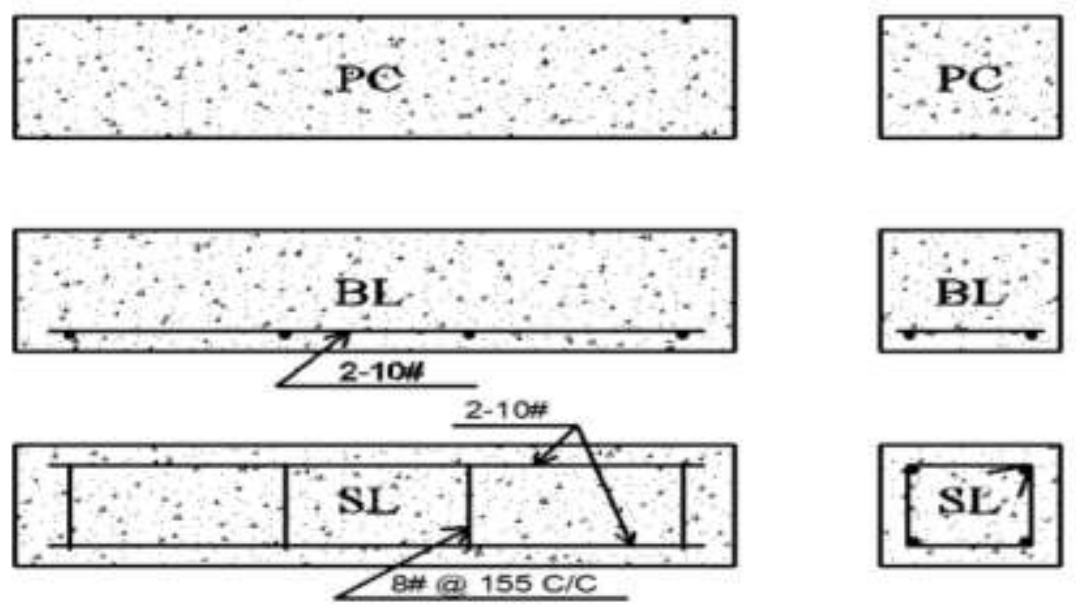

Figure 1 - Schematic front view and cross section of un-strengthened (control) beams 

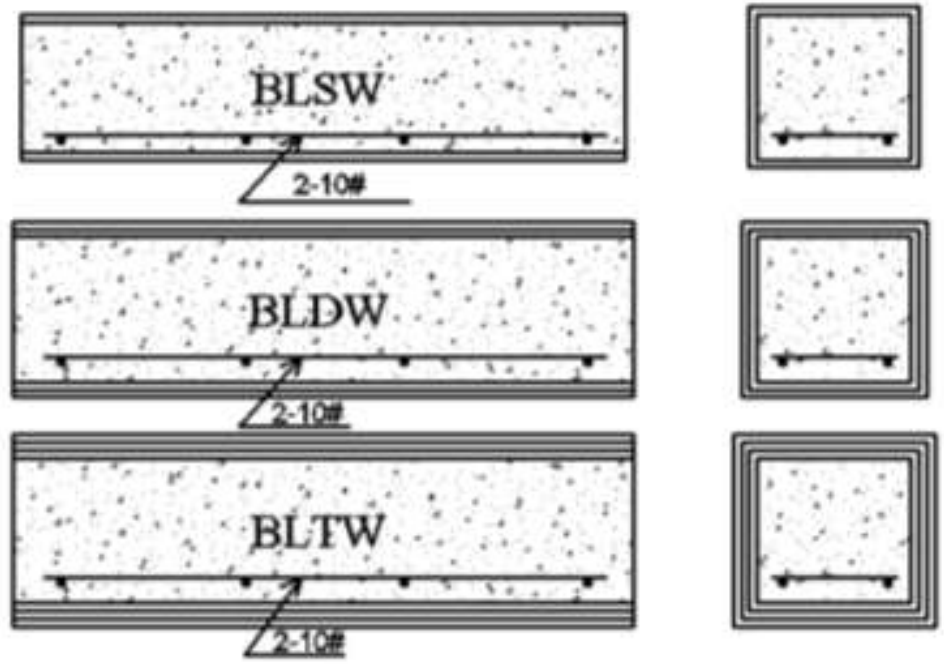

Figure 2 - Schematic front view and cross section of beams strengthened with externally bonded GFRP wrap in single, double and triple layer on four sides of beam

The beams were strengthened using externally bonded bidirectional non crimp fibers $\left(0^{0}-90^{0}\right)$ bonded using general purpose resin to a reinforced beam on 28 days of continuous water curing. The three numbers of concrete cubes for 7 days and 28 days of continuous water curing were investigated for the determination of compressive strength of concrete. In case of un-strengthened beams each type of beam with single number were investigated on 28 days of continuous water curing and in case of strengthened beams, the strengthening of beams was done on 28 days of water curing and then the beams were strengthened and air cured for 48 hours ( 2 days) and single number of each type was investigated.

\subsection{Materials}

\subsubsection{Cement}

Ordinary Portland cement of 53 grade form JAYPEE India Cements make was used for the entire work.

\subsubsection{Steel Reinforcement}

The maker of steel reinforcement is SHREE OM and Fe500 grade HYSD reinforcement confirming to IS 1786:2008.

\subsubsection{Fine Aggregates}

The locally available fine aggregate from the river beds of Godavari; passing through $0.18 \mathrm{in}$. [4.75 mm] sieve was used for all experimental investigations and product considered in this study. The specific gravity, water absorption, and fineness modulus of sand (passing through $0.18 \mathrm{in}$. [4.75 mm] sieve opening size) are 2.70, 1.93 and 2.99 respectively. The grading of sand conforms to the zone-II of IS: 383-1970.

\subsubsection{Coarse Aggregates}

Machine crushed locally available hard basalt, well graded $20 \mathrm{~mm}$ and down size was used. The specific gravity, water absorption, and fineness modulus of sand (passing through 0.79 in. $[20 \mathrm{~mm}]$ sieve opening size) are $2.74,0.60$ and 7.41 respectively.

The proportion of ingredient materials for design mix of M20 grade as per IS 10262-2009 is as shown in Table 2.

Table 2 - Mix design for M20 concrete

\begin{tabular}{|c|c|c|c|c|}
\hline $\begin{array}{l}\text { Sr. } \\
\text { No. }\end{array}$ & Ingredient Particulars & $\begin{array}{l}\text { Proportion by } \\
\text { weight }\end{array}$ & $\begin{array}{l}\text { Quantity for } 1 \mathrm{~m}^{3} \text { of } \\
\text { concrete, lb }(\mathrm{kg})\end{array}$ & $\begin{array}{l}\text { Quantity for One bag of } \\
\text { cement, lb (kg) }\end{array}$ \\
\hline 1 & Cement & 1 & $818.40(372.00)$ & $110.00(50.00)$ \\
\hline 2 & Water & 0.5 & $409.20(186.00)$ & $55.00(25.00)$ \\
\hline 3 & Fine aggregate & 2.02 & $1653.70(751.68)$ & $222.20(101.00)$ \\
\hline 4 & Coarse aggregate & 3.07 & $2517.28(1144.22)$ & $337.70(153.50)$ \\
\hline
\end{tabular}

\subsubsection{Glass Fiber Reinforced Polymer (GFRP)}

A new material form Saertex India Pvt. Ltd. is getting wider attention which is known as NCFs (NonCrimp Fabrics) as in shown Fig. 3, are characterized by stretched fibers within the individual layers. Multi-axial interlaid complexes (Non Crimped Fibers (NCFs)) of variable orientation and individual layer arrangement always exhibit the best mechanical characteristic values [5]. The externally bonded GFRP wrap selected for strengthening of the RC beams herein the experimental work was the bidirectional complex in orientations of 
$0^{0} / 90^{\circ}$, whose weight is $631 \mathrm{~g} / \mathrm{m}^{2}$. The typical sketch of the bidirectional complex is as shown in Fig. 4. Details of the Bidirectional complex used are as below:

i. Stitching pattern: tricot-warp

ii. Gauge: 7.0

iii. Width: $1210 \mathrm{~mm}$

iv. Total areal weight: $631 \mathrm{~g} / \mathrm{m}^{2}$

v. Total tolerance: $5.4 \%$

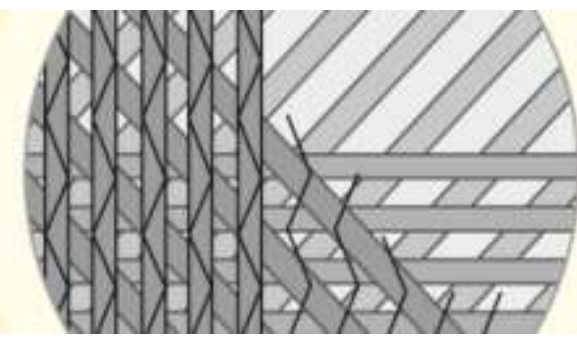

Figure 3 - Non crimp fiber

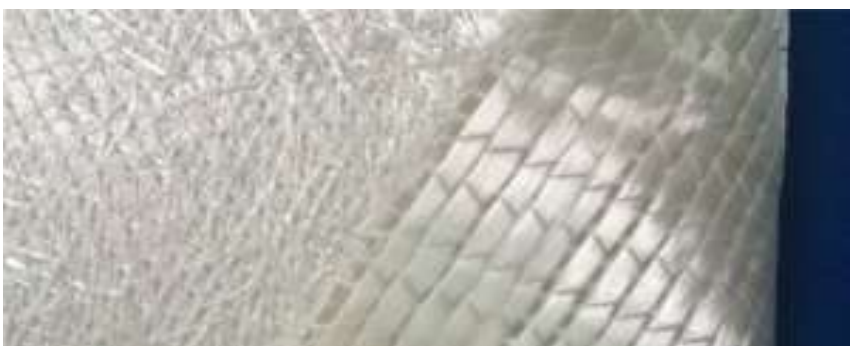

Figure 4 - Biaxial stitched glass fiber fabric

The bidirectional laminate is made out of E-glass 1200/600 tex of single end rovings stitched together with PES dtex in either direction. Some of the properties of the GFRP materials are as discussed below:

i. Type of the fiber - Direct roving's glass fiber

ii. Density of direct roving glass fiber $=2.60 \mathrm{gm} / \mathrm{cc}$

iii. Available tex $=1200 / 600 \mathrm{gm} / \mathrm{km}$.

iv. Young's modulus of glass fiber $=80 \mathrm{GPa}$

v. Tensile strength of glass direct roving $=2$ to $3 \mathrm{GPa}$

The datasheet of bidirectional complex is as shown in Fig. 5.

\begin{tabular}{|c|c|c|c|c|}
\hline $\mathrm{Z}$ & & & & \\
\hline CONSTRUCTION & $\begin{array}{l}\text { AREAL } \\
\left(\mathrm{g} / \mathrm{m}^{2}\right)\end{array}$ & TOLERANCE $(+/-\%)$ & MATERIAL & \\
\hline UPPER SIDE & & & & \\
\hline $0^{0}$ & 331 & 5 & E-Glass 1200 TEX & $\mathrm{X}, \mathrm{Y}$ \\
\hline $90^{\circ}$ & 288 & 5 & E-Glass 600 TEX & \\
\hline LOWER SIDE & & & & \\
\hline STITCHING & $12 \mathrm{~g} / \mathrm{m}^{2}$ & PES (POLY & STER) $110 \mathrm{dtex}$ & \\
\hline
\end{tabular}

Figure 5 - Datasheet of bidirectional complex

\subsubsection{Resin}

In fiber reinforced polymers, the polymer (or the resin) phase constitutes the binding phase and strong and stiff fibers constitute the fiber phase. Two types of polymers are currently in use: thermosetting polymer and the thermoplastic polymers. The thermosetting polymers are ideally suited for FRPs in civil engineering applications [6].

espol $^{\mathrm{TM}}$ is the brand-name for the specially formulated unsaturated polyester resin synthesized at Satyen Polymers Private Limited. The superior general purpose polyester resin espol ${ }^{\mathrm{TM}}$ is a quick curing unsaturated polyester resin based on Orthophthalic grade for special laminating purpose. Suitable for both hand lay-up and gun spray up. Physical data in liquid state at $25^{\circ} \mathrm{C}$ [Confirm to IS 6746-1994 and BS 3532-1990]

i. Name of the resin used - Orthophthalic General Purpose (GP) Plain ESPOL ${ }^{\mathrm{TM}} 12.00$

ii. Polymer group - Thermoset Resin.

iii. Type of Thermoset - Unsaturated Polyester Resin. 
iv. Specific gravity of general purpose resin $=1.12 \mathrm{gm} / \mathrm{cc}$.

v. Viscosity of resin $=115-550 \mathrm{cal} / \mathrm{sec} @ 30^{\circ} \mathrm{C}$.

vi. Gel time $=15-18$ minutes

vii. Hardens at temp. $=70^{\circ}-185^{\circ} \mathrm{C}$

viii. Tensile strength $=45-55 \mathrm{~N} / \mathrm{mm}^{2}$

ix. Flexural Strength $=70-90 \mathrm{~N} / \mathrm{mm}^{2}$

x. Young's Modulus $=1.84 \mathrm{GPa}$

Once the surface was prepared to the required standard, using Accelerator, Co (2\%) $1 \mathrm{ml}$, Catalyst, Methyl Ethyl Ketone Peroxide (MEKP) $1.5 \mathrm{ml}$, the gel time, cure time and Peak Exotherm measured were used with general purpose (GP) resin for the preparation of the matrix for bonding between reinforced concrete beams and GFRP wraps bonded externally. Always mix the MEKP into the resin for at least 2 minutes; undermixing will result in uncured resin.

\subsection{Specimens}

The six numbers of concrete cube specimens of size $(5.90 \mathrm{in}$. [150 mm] width $\times 5.90 \mathrm{in}$. [150 mm] depth $\times 5.90$ in. $[150 \mathrm{~mm}]$ length) were investigated. The compression strength test setup is as shown in Fig. 6.

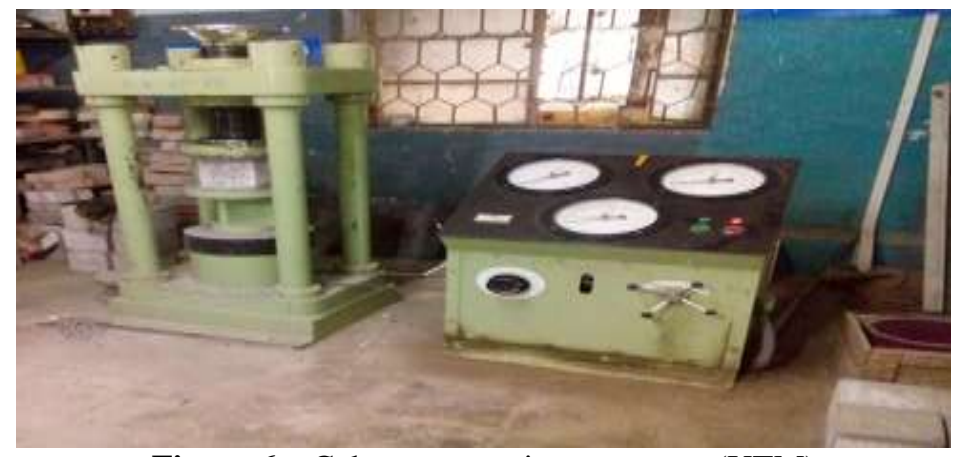

Figure 6 - Cube compression test setup (UTM)

The six number of concrete beam specimens of size $(5.90 \mathrm{in}$. [150 mm] width $\times 5.90$ in. [150 mm] depth $\times$ 27.56 in. [700 mm] length) were investigated and the test setup is as shown in Fig. 7.

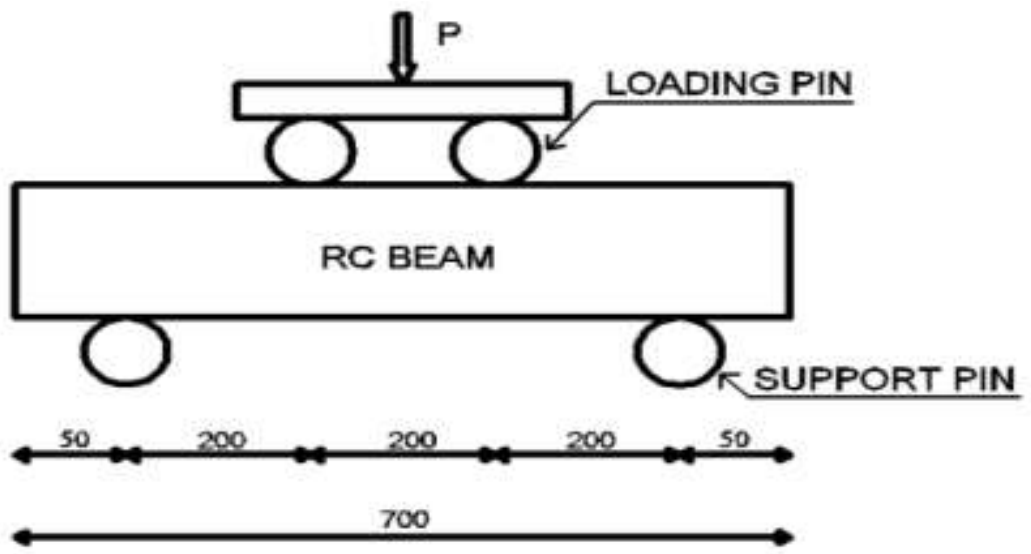

Figure 7 - Experimental setup for flexural strength tests of beam

\subsection{Items of Investigation}

Three numbers of concrete cube specimens each were tested under Universal Testing Machine (UTM) for the determination of compressive strength at 7 days and 28 days of water curing respectively. The unstrengthened beams (on 28 days of water curing) and beams strengthened with externally bonded GFRP wraps (on 28 days of water curing and 2 days of air curing on strengthening) were tested flexural strength using four point load test as specified in the IS 516:1959. The shear force and bending moment diagrams for Four Point Loading of the beam specimen is as shown in Fig. 8 


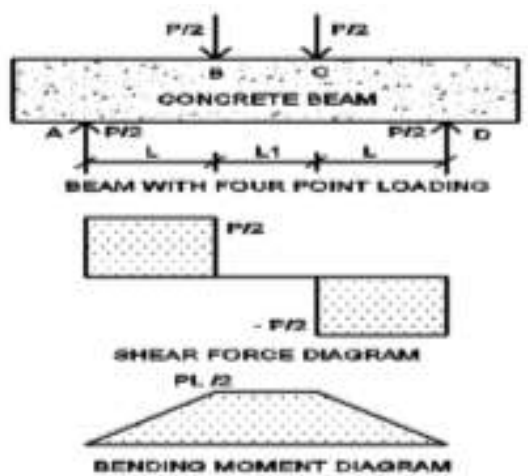

Figure 8 - Shear force and bending moment diagram for four point load test of beam

\subsection{Compressive Strength}

\section{Experimental Results And Discussion}

The compressive strength of concrete at 7 and 28 days of continuous water curing are as shown in the Table 3 .

Table 3 - Compressive strength test results of concrete cubes

\begin{tabular}{|c|c|c|c|c|c|c|c|c|}
\hline $\begin{array}{l}\text { Sr. } \\
\text { No. }\end{array}$ & $\begin{array}{l}\text { Cube } \\
\text { Id }\end{array}$ & $\begin{array}{l}\text { Weight, } \\
\text { lb (kg) }\end{array}$ & $\begin{array}{ll}\begin{array}{l}\text { Density } \\
\left(\mathrm{kg} / \mathrm{m}^{3}\right)\end{array} & \mathbf{l b} / \mathbf{f t}^{3}\end{array}$ & Days & $\begin{array}{l}\text { Load, } \\
\text { kips } \\
(\mathbf{k N})\end{array}$ & $\begin{array}{l}\text { Area } \\
\text { Cube } \\
\left(\mathbf{m m}^{2}\right)\end{array}$ & $\begin{array}{l}\text { Compressive } \\
\text { Strength, } \\
\text { psi }\left(\mathbf{N} / \mathbf{m m}^{2}\right)\end{array}$ & $\begin{array}{l}\text { Avg. comp. } \\
\text { strength, } \\
\text { psi }\left(\mathbf{N} / \mathbf{m m}^{2}\right)\end{array}$ \\
\hline 1 & $\mathrm{C} 01$ & $\begin{array}{l}19.03 \\
(8.65)\end{array}$ & $160.01(2562.96)$ & \multirow[t]{3}{*}{7} & $\begin{array}{l}76.43 \\
(340)\end{array}$ & \multirow[t]{6}{*}{$\begin{array}{l}150 \times 150= \\
22500\end{array}$} & $2191.52(15.11)$ & \multirow[t]{3}{*}{$2384.42(16.44)$} \\
\hline 2 & $\mathrm{C} 02$ & $\begin{array}{l}19.36 \\
(8.80) \\
\end{array}$ & $162.78(2607.40)$ & & $\begin{array}{l}85.43 \\
(380)\end{array}$ & & $2449.69(16.89)$ & \\
\hline 3 & $\mathrm{C} 03$ & $\begin{array}{l}19.14 \\
(8.70) \\
\end{array}$ & $160.93(2577.78)$ & & $\begin{array}{l}87.68 \\
(390)\end{array}$ & & $2513.50(17.33)$ & \\
\hline 4 & C04 & $\begin{array}{l}19.47 \\
(8.85)\end{array}$ & $163.71(2622.22)$ & \multirow[t]{3}{*}{28} & $\begin{array}{l}155.12 \\
(690)\end{array}$ & & 4446.86 (30.66) & \multirow[t]{3}{*}{$4413.50(30.43)$} \\
\hline 5 & $\mathrm{C} 05$ & $\begin{array}{l}19.36 \\
(8.80) \\
\end{array}$ & $162.78(2607.40)$ & & $\begin{array}{l}156.24 \\
(695)\end{array}$ & & $4478.76(30.88)$ & \\
\hline 6 & C06 & $\begin{array}{l}18.92 \\
(8.60)\end{array}$ & $159.08(2548.15)$ & & $\begin{array}{l}150.62 \\
(670)\end{array}$ & & 4317.77 (29.77) & \\
\hline
\end{tabular}

\subsection{Load-Deflection Relationship}

The load-deflection relationship for the un-strengthened beams is as shown in Fig. 9. The increase in ultimate load and deflection at ultimate load is observed among these beams when provided with steel reinforcement. The load-deflection relationship for the beams strengthened with externally bonded GFRP wraps is as shown in Fig. 10. The increase in ultimate load and deflection at ultimate load is observed as the increase in number of layers of externally bonded GFRP wraps was made till three numbers of the layers.

\subsection{Comparison of Ultimate Load Carrying Capacity and Deflection of Beams}

The comparison of ultimate load carrying capacity and deflection of beams had been made between the three un-strengthened beams; considering each as a control beam and the three strengthened beams on the other hand for three different cases of control beams. And, the comparison of the same between the beams strengthened with externally bonded single layer of GFRP as a control beam and other two strengthened beams with double and triple layer of externally bonded GFRP respectively on other hand.

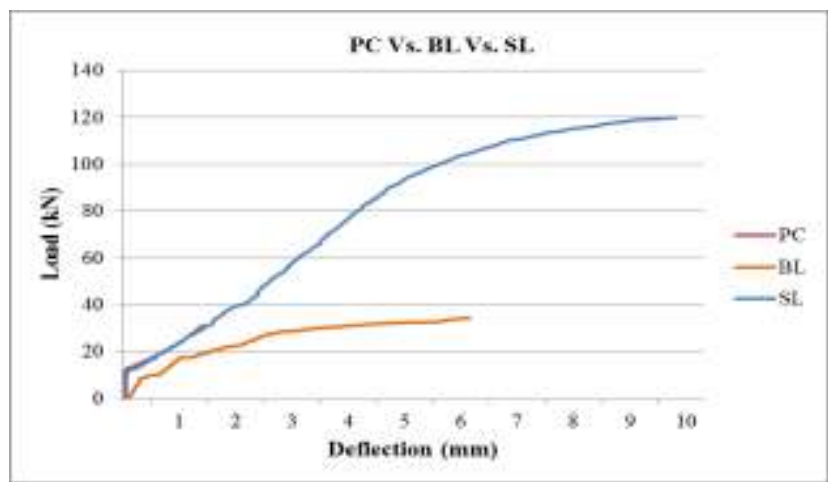

Figure 9 - Load vs. Central deflection relationship for control beams 


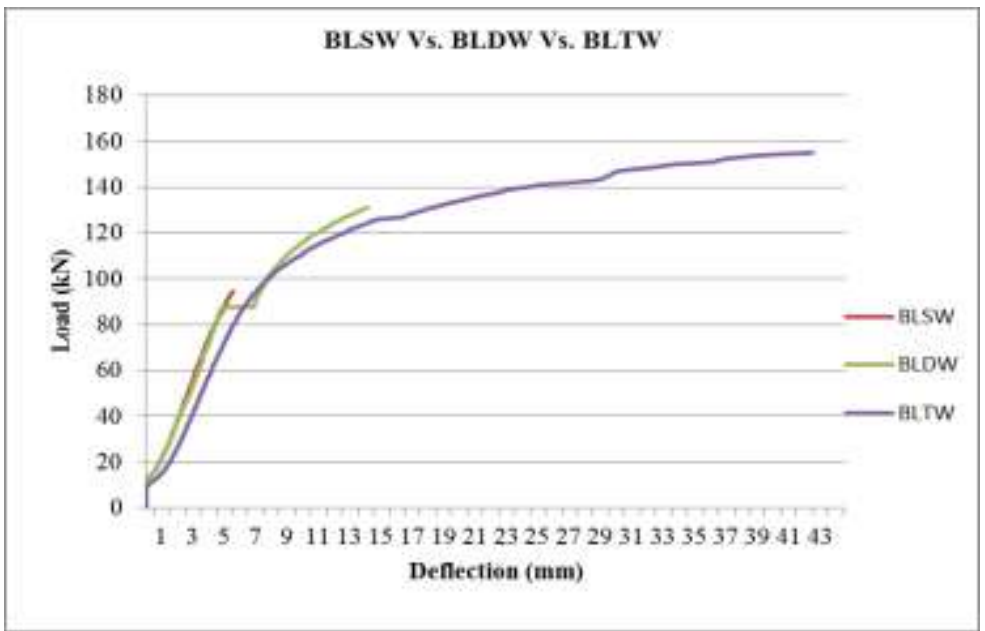

Figure 10 - Load vs. Central deflection relationship for beams strengthened with GFRP wraps

\subsection{Comparison of Ultimate Load Carrying Capacity and Deflection of Beams}

The comparison of ultimate load carrying capacity and deflection of beams had been made between the three un-strengthened beams; considering each as a control beam and the three strengthened beams on the other hand for three different cases of control beams. And, the comparison of the same between the beams strengthened with externally bonded single layer of GFRP as a control beam and other two strengthened beams with double and triple layer of externally bonded GFRP respectively on other hand.

Table 4 - Flexural Strength Test Results of Beam

\begin{tabular}{|l|l|l|l|l|l|}
\hline $\begin{array}{l}\text { Sr. } \\
\text { No. }\end{array}$ & Beam Designation & $\begin{array}{l}\text { C/C Distance of } \\
\text { Support, in. (mm) }\end{array}$ & $\begin{array}{l}\text { Ultimate Load, } \\
\text { kips (kN) }\end{array}$ & $\begin{array}{l}\text { Ultimate } \\
\text { Deflection (mm) }\end{array}$ & Remark \\
\hline 1 & PC & $23.62(600)$ & $6.97(31.00)$ & 1.41 & Control Beam \\
\hline 2 & BL & $23.62(600)$ & $7.71(34.29)$ & 6.15 & Control Beam \\
\hline 3 & SL & $23.62(600)$ & $26.98(120.00)$ & 9.80 & Control Beam \\
\hline 4 & BLSW & $23.62(600)$ & $21.24(94.50)$ & 5.58 & Control Beam \\
\hline 5 & BLDW & $23.62(600)$ & $29.45(131.00)$ & 14.13 & \\
\hline 6 & BLTW & $23.62(600)$ & $34.85(155.00)$ & 42.50 & \\
\hline
\end{tabular}

The flexural strength test results using four point load test are as shown in Table $\mathbf{4}$ and the results of ultimate loads are represented in the form of bar chart by Fig. 11 and results of respective ultimate deflections are shown in the form of line graph in Fig. 12.

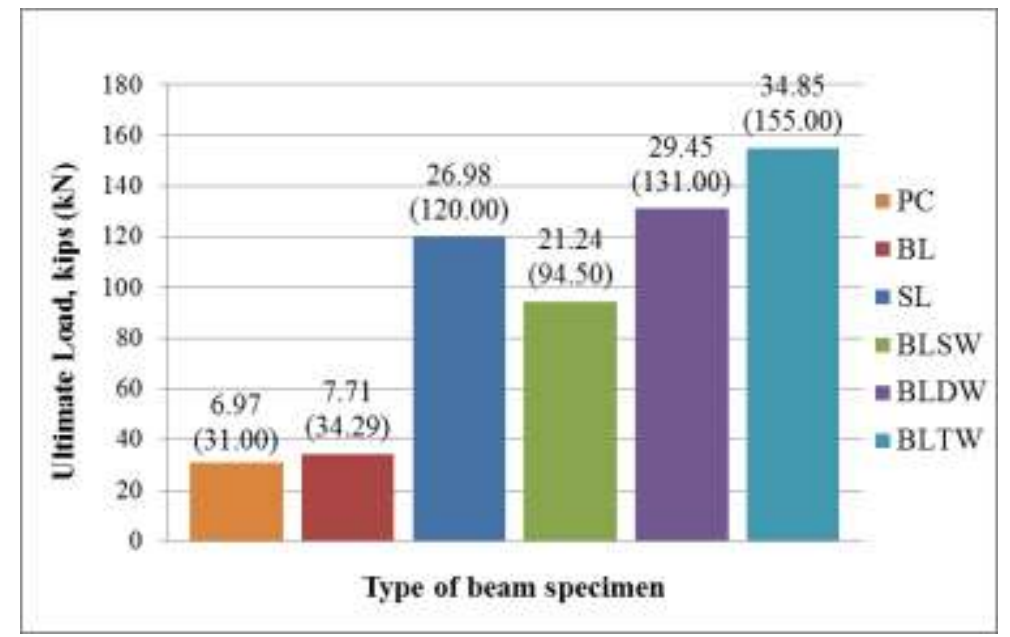

Figure 11 - Bar Chart showing ultimate load carrying capacity of beams 


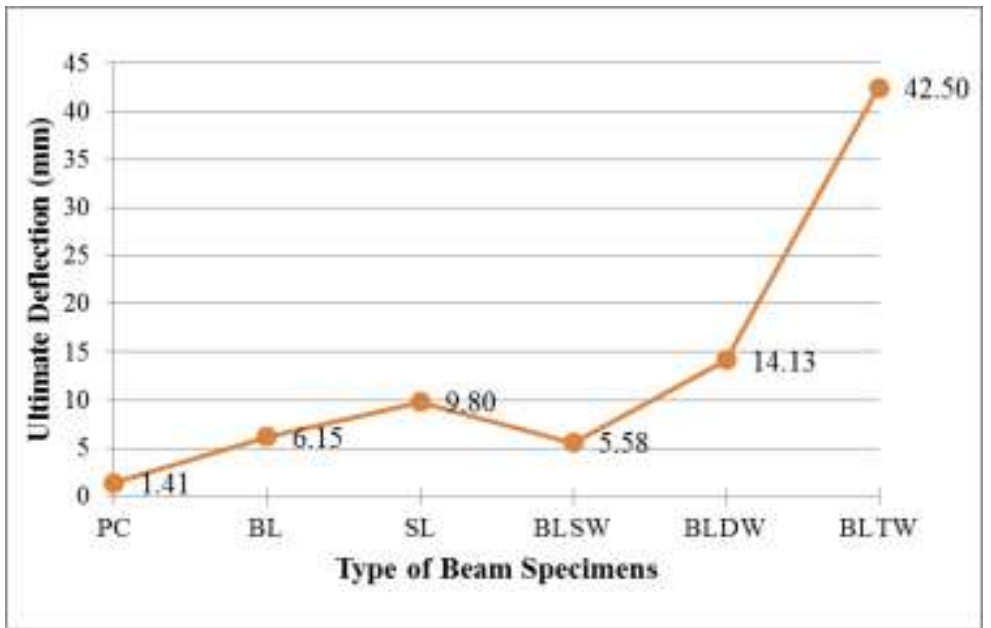

Figure 12 - Line graph showing ultimate deflection at the centre for all beams

4.4.1 Case-I: Plain concrete beam (PC) as a control beam

Table 5 - Comparison of Ultimate load carrying capacity and deflection between beam PC and strengthened beams with externally bonded technique

\begin{tabular}{|c|c|c|c|c|c|c|c|c|c|c|}
\hline \multirow[t]{2}{*}{$\begin{array}{l}\text { Sr. } \\
\text { No. }\end{array}$} & \multirow[t]{2}{*}{ Beam Id } & \multirow{2}{*}{$\begin{array}{l}\text { Wrappi } \\
\text { ng } \\
\text { Pattern }\end{array}$} & \multirow{2}{*}{$\begin{array}{l}\text { C/C Distance } \\
\text { of Support, } \\
\text { in. }(\mathrm{mm})\end{array}$} & \multirow[t]{2}{*}{$\begin{array}{l}\text { Load, } \\
\text { kips (kN) }\end{array}$} & \multicolumn{2}{|c|}{ Change in load } & \multirow[t]{2}{*}{$\begin{array}{l}\text { Deflecti- } \\
\text { on (mm) }\end{array}$} & \multicolumn{2}{|c|}{$\begin{array}{ll}\begin{array}{l}\text { Change } \\
\text { deflection }\end{array} & \text { in }\end{array}$} & \multirow[t]{2}{*}{ Remark } \\
\hline & & & & & In $\%$ & In times & & In \% & In times & \\
\hline 1 & $\mathrm{PC}$ & $\mathrm{NA}$ & $23.62(600)$ & $\begin{array}{l}6.97 \\
(31.00)\end{array}$ & 100 & 1.00 & 1.41 & 100 & 1.00 & $\begin{array}{l}\text { Control } \\
\text { Beam }\end{array}$ \\
\hline 2 & BLSW & Single & $23.62(600)$ & $\begin{array}{l}21.24 \\
(94.50)\end{array}$ & 305 & 3.05 & 5.58 & 396 & 3.96 & \\
\hline 3 & BLDW & Double & $23.62(600)$ & $\begin{array}{l}29.45 \\
(131.00)\end{array}$ & 423 & 4.23 & 14.13 & 1002 & 10.02 & \\
\hline 4 & BLTW & Triple & $23.62(600)$ & $\begin{array}{l}34.85 \\
(155.00)\end{array}$ & 500 & 5.00 & 42.50 & 3014 & 30.14 & \\
\hline
\end{tabular}

For four different cases, the results of flexural strength test are as shown in Table 5, Table 6, Table 7 and Table 8 respectively. The comparison among them with respect to percentage increase in load carrying capacity is shown in the form of bar chart by Fig. 13, Fig. 14, Fig. 15 and Fig. 16. And, the percentage change in ultimate deflection can be studied from the respective tables. The concluding remarks of comparison among various beams have been stated under the conclusions with respect to the respective control beams for change in load carrying capacity and deflection.

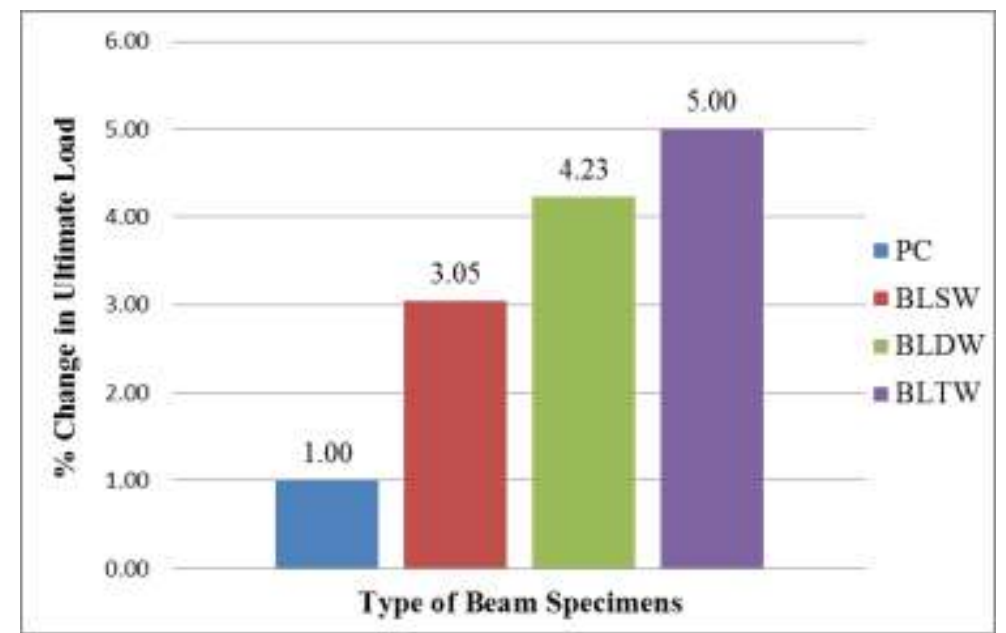

Figure 13 - Bar Chart showing comparison of percentage increase in ultimate load carrying capacity of strengthened beams when compared to a control beam PC

4.4.2 Case-II: Beam reinforced with tension reinforcement (BL) as a control beam 
Table 6 - Comparison of Ultimate load carrying capacity and deflection between beam BL and strengthened beams with externally bonded technique

\begin{tabular}{|c|c|c|c|c|c|c|c|c|c|c|}
\hline \multirow[t]{2}{*}{$\begin{array}{l}\text { Sr. } \\
\text { No. }\end{array}$} & \multirow[t]{2}{*}{ Beam Id } & \multirow[t]{2}{*}{$\begin{array}{l}\text { Wrappin } \\
\text { g Pattern }\end{array}$} & \multirow{2}{*}{$\begin{array}{l}\text { C/C Distance of } \\
\text { Support, in. } \\
\text { (mm) }\end{array}$} & \multirow[t]{2}{*}{ Load, kips (kN) } & \multicolumn{2}{|c|}{ Change in load } & \multirow[t]{2}{*}{$\begin{array}{l}\text { Deflecti- } \\
\text { on (mm) }\end{array}$} & \multicolumn{2}{|c|}{$\begin{array}{ll}\begin{array}{l}\text { Change } \\
\text { deflection }\end{array} & \text { in } \\
\end{array}$} & \multirow[t]{2}{*}{ Remark } \\
\hline & & & & & In $\%$ & In times & & In $\%$ & In times & \\
\hline 1 & $\mathrm{BL}$ & NA & $23.62(600)$ & $7.71(34.29)$ & 100 & 1.00 & 6.15 & 100 & 1.00 & $\begin{array}{l}\text { Control } \\
\text { Beam } \\
\end{array}$ \\
\hline 2 & BLSW & Single & $23.62(600)$ & $21.24(94.50)$ & 276 & 2.76 & 5.58 & 91 & 0.91 & \\
\hline 3 & BLDW & Double & $23.62(600)$ & $29.45(131.00)$ & 382 & 3.82 & 14.13 & 230 & 2.30 & \\
\hline 4 & BLTW & Triple & $23.62(600)$ & $34.85(155.00)$ & 452 & 4.52 & 42.50 & 691 & 6.91 & \\
\hline
\end{tabular}

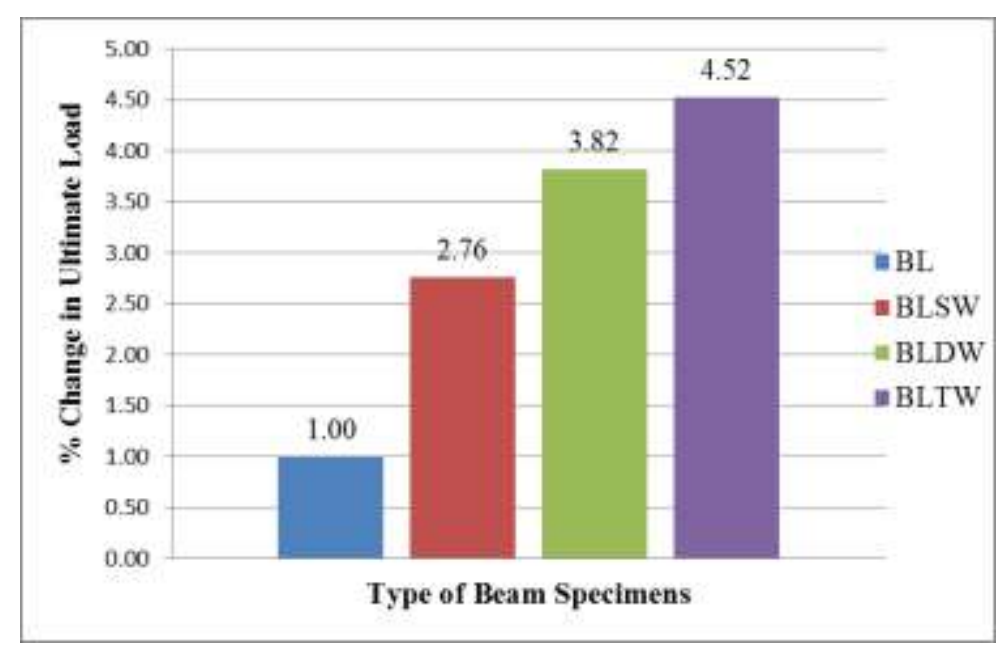

Figure 14 - Bar Chart showing comparison of percentage increase in ultimate load carrying capacity of strengthened beams when compared to a control beam BL

4.4.3 Case-III: Beam reinforced with tension, compression and shear reinforcement (SL) as a control beam

Table 7 - Comparison of Ultimate load carrying capacity and deflection between beam SL and strengthened beams with externally bonded technique

\begin{tabular}{|c|c|c|c|c|c|c|c|c|c|c|}
\hline \multirow[t]{2}{*}{$\begin{array}{l}\text { Sr. } \\
\text { No. }\end{array}$} & \multirow[t]{2}{*}{ Beam Id } & \multirow[t]{2}{*}{$\begin{array}{l}\text { Wrapping } \\
\text { Pattern }\end{array}$} & \multirow{2}{*}{$\begin{array}{l}\text { C/C Distance } \\
\text { of Support, in. } \\
(\mathrm{mm})\end{array}$} & \multirow[t]{2}{*}{ Load, kips (kN) } & \multicolumn{2}{|c|}{ Change in load } & \multirow{2}{*}{$\begin{array}{l}\text { Deflec } \\
\text { tion } \\
(\mathrm{mm})\end{array}$} & \multicolumn{2}{|c|}{$\begin{array}{l}\text { Change } \\
\text { deflection }\end{array}$} & \multirow[t]{2}{*}{ Remark } \\
\hline & & & & & In $\%$ & In times & & In $\%$ & In times & \\
\hline 1 & SL & NA & $23.62(600)$ & $26.98(120.00)$ & 100 & 1.00 & 9.80 & 100 & 1.00 & $\begin{array}{l}\text { Control } \\
\text { Beam }\end{array}$ \\
\hline 2 & BLSW & Single & $23.62(600)$ & $21.24(94.50)$ & 79 & 0.79 & 5.58 & 57 & 0.57 & \\
\hline 3 & BLDW & Double & $23.62(600)$ & $29.45(131.00)$ & 109 & 1.09 & 14.13 & 144 & 1.44 & \\
\hline 4 & BLTW & Triple & $23.62(600)$ & $34.85(155.00)$ & 129 & 1.29 & 42.50 & 434 & 4.34 & \\
\hline
\end{tabular}

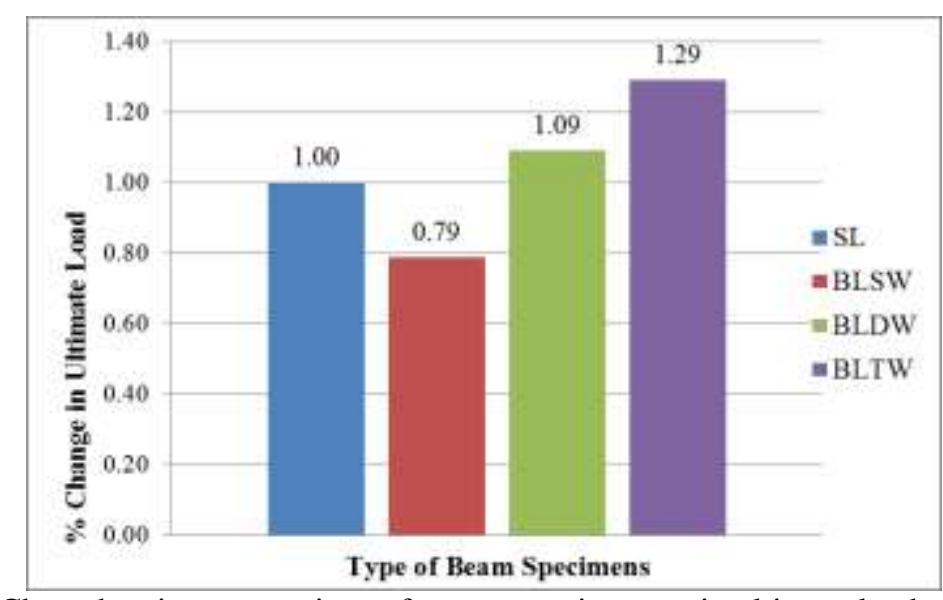

Figure 15 - Bar Chart showing comparison of percentage increase in ultimate load carrying capacity of strengthened beams when compared to a control beam SL 
4.4.4 Case-IV: Beam (BL) externally bonded with GFRP wrap in single layer as a control beam

Table 8 - Comparison of Ultimate load carrying capacity and deflection between beam BLSW and other strengthened beams with externally bonded technique

\begin{tabular}{|c|c|c|c|c|c|c|c|c|c|c|}
\hline \multirow{2}{*}{$\begin{array}{l}\text { Sr. } \\
\text { No. }\end{array}$} & \multirow{2}{*}{$\begin{array}{l}\text { Beam } \\
\text { Id }\end{array}$} & \multirow{2}{*}{$\begin{array}{l}\text { Wrappin } \\
\text { g Pattern }\end{array}$} & \multirow{2}{*}{$\begin{array}{l}\text { C/C } \\
\text { Distance of } \\
\text { Support, in. } \\
\text { (mm) }\end{array}$} & \multirow{2}{*}{$\begin{array}{l}\text { Load, } \\
(\mathrm{kN})\end{array}$} & \multicolumn{2}{|c|}{$\begin{array}{l}\text { Change in } \\
\text { load }\end{array}$} & \multirow{2}{*}{$\begin{array}{l}\text { Defle } \\
\text { ction } \\
(\mathrm{mm})\end{array}$} & \multicolumn{2}{|c|}{$\begin{array}{l}\text { Change in } \\
\text { deflection }\end{array}$} & \multirow{2}{*}{$\begin{array}{l}\text { Remar } \\
\mathbf{k}\end{array}$} \\
\hline & & & & & $\begin{array}{l}\text { In } \\
\%\end{array}$ & $\begin{array}{l}\text { In } \\
\text { times }\end{array}$ & & $\begin{array}{l}\text { In } \\
\%\end{array}$ & $\begin{array}{l}\text { In } \\
\text { times }\end{array}$ & \\
\hline 1 & BLSW & Single & $23.62(600)$ & $21.24(94.50)$ & 100 & 1.00 & 5.58 & 100 & 1.00 & $\begin{array}{l}\text { Control } \\
\text { Beam }\end{array}$ \\
\hline 2 & BLDW & Double & $23.62(600)$ & $29.45(131.00)$ & 139 & 1.39 & 14.13 & 253 & 2.53 & \\
\hline 3 & BLTW & Triple & $23.62(600)$ & $34.85(155.00)$ & 164 & 1.64 & 42.50 & 762 & 7.62 & \\
\hline
\end{tabular}

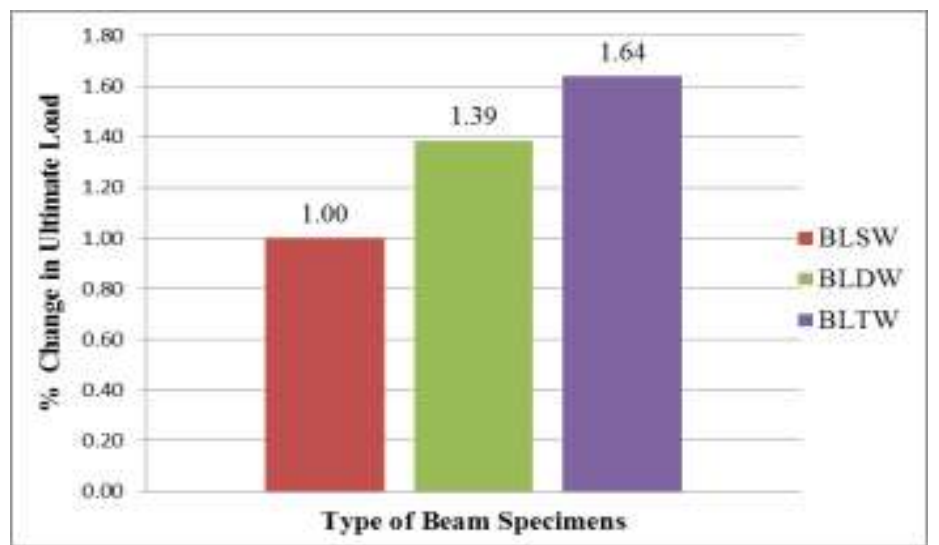

Figure 16 - Bar Chart showing comparison of percentage increase in ultimate load carrying capacity of strengthened beams when compared to a control beam BLSW

\subsection{Mode of Failure}

The plain concrete beam fails in flexure as shown in Fig. 17 and a shear failure mode was observed in the beams provided with reinforcement as shown in Fig. 18.

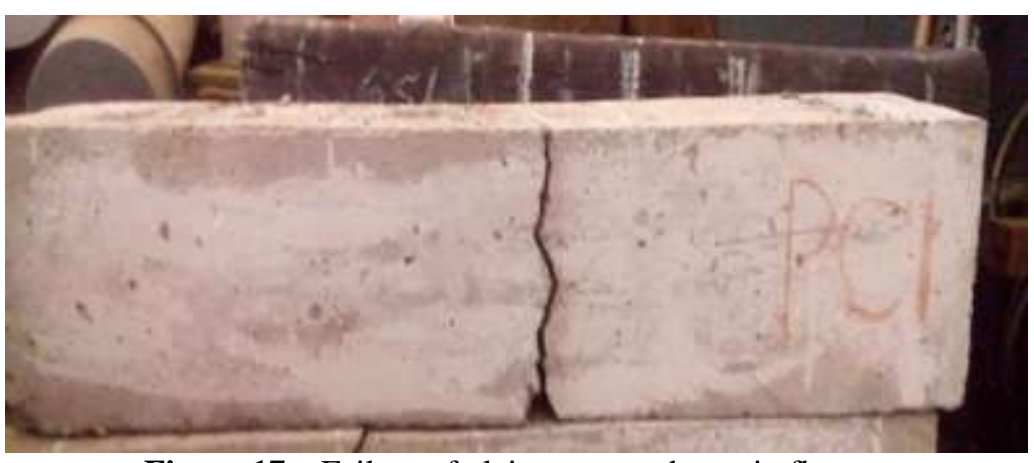

Figure 17 - Failure of plain concrete beam in flexure

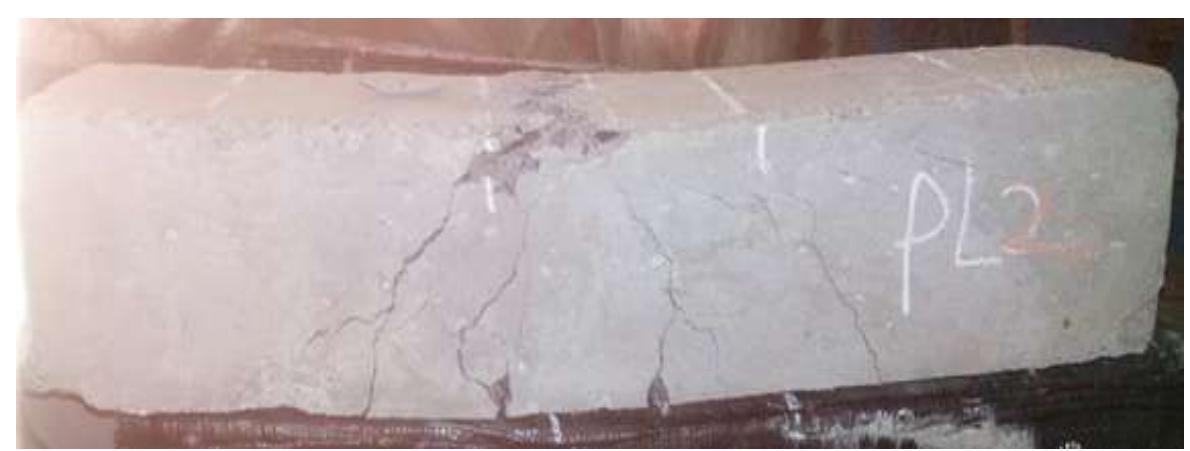

Figure 18 - Failure of reinforced concrete beam (BL) in shear 
The cracking pattern and mode of failure of reinforced concrete beam when strengthened using externally bonded technique is shown in Fig. 19 by tearing the GFRP wrap on failure and observing the beam. The beams (provided with tension steel reinforcement) strengthened using externally bonded glass fiber reinforced polymer in single, double and triple layer did failed in shear at ultimate load but at a relatively higher load when compared to a un-strengthened control beam (with tension reinforcement). The deflection of strengthened beam is much more than un-strengthened beam which shows change or shift of beam failure mode from shear to flexure of the beam before failure. The mode of failure of beam strengthened with externally bonded GFRP wraps is shown in figure 20.

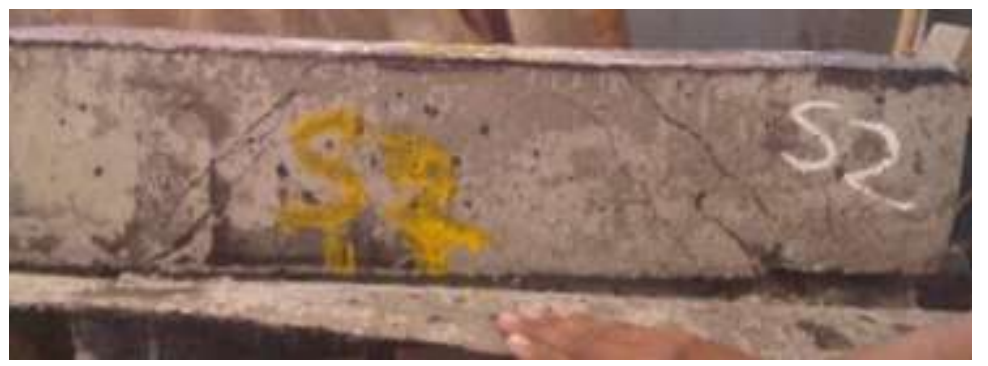

Figure 19 - Failure of reinforced concrete beam provided with externally bonded GFRP wrap

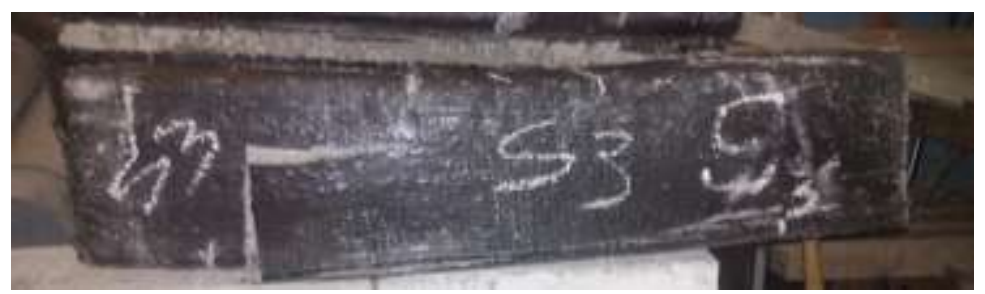

(A): Single Layer Wrap

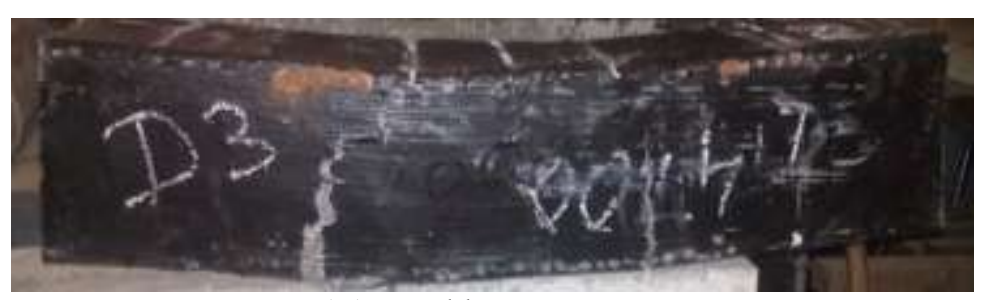

(B): Double Layer Wrap

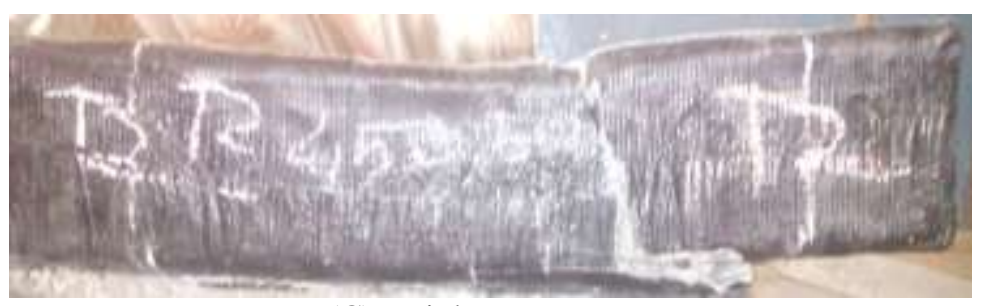

(C): Triple Layer Wrap

Figure 20 - Failure of reinforced concrete beam provided with externally bonded GFRP wrap

\section{Further Research}

It is desirable to test beam specimens strengthened with different type, shape, orientation and weight of glass fiber reinforced polymer wraps and different locations of the beam specimen for wrapping. The efforts should be made to find out the effective type of GFRP for retrofitting of the member thereby enhancing the shear capacity of the member and a substitute over the replacement of the member. The same study can also be made using other types of fiber reinforced polymers such as carbon fiber reinforced polymer (CFRP).

The research also can be made with the beams accompanied by reinforced concrete slab as well, as we know by conducting this experimental work that the beams shear capacity increases upon the application of externally bonded GFRP wraps and find the inter-relationships thereof. 


\section{Conclusions}

Based on the results of this experimental investigation of beams externally bonded with glass fiber reinforced polymer wraps in single, double and triple layers, the following conclusions are drawn:

6.1. The retrofitting of beams using externally bonded glass fiber reinforced polymer wraps resulted in an increase in the load carrying capacity of the beam. And, it also resisted the shear forces to a great extent thereby increasing the load carrying capacity of the beams.

6.2. An increase in load carrying capacity of $1.11,3.87$ times was observed in beam with tension reinforcement (BL) and other beam with top, bottom and shear reinforcement (SL) respectively over a plain concrete beam (PC) for M20 concrete mix.

6.3. The nature of beam failure for a plain concrete beam was in flexure and that for the beam provided with steel reinforcement was in shear.

6.4. The ultimate deflection for beam with tension reinforcement (BL) and beam with top, bottom and shear reinforcement (SL) was 1.59 and 5.57 times that of the ultimate deflection of control beam (PC).

6.5. The increase in load carrying capacity of strengthened beams BLSW, BLDW and BLTW was 3.05, 4.23 and 5.00 times respectively when compared to a control beam of plain concrete PC. And, the corresponding positive changes in ultimate deflection were 3.96, 10.02 and 30.14 times in beam BLSW, BLDW and BLTW respectively to that of control beam PC.

6.6. The increase in load carrying capacity of strengthened beams BLSW, BLDW and BLTW was 2.76, 3.82 and 4.52 times respectively when compared to a control beam of reinforced concrete BL. And, the corresponding changes in ultimate deflection were 0.91, 2.30 and 6.91 times in beam BLSW, BLDW and BLTW respectively to that of control beam BL.

6.7. The change in load carrying capacity of strengthened beams BLSW, BLDW and BLTW was $0.79,1.09$ and 1.29 times respectively when compared to a control beam of reinforced concrete SL. And, the corresponding changes in ultimate deflection were 0.57, 1.44 and 4.34 times in beam BLSW, BLDW and BLTW respectively to that of control beam SL.

6.8. An enhancement in load carrying capacity of strengthened beams BLDW and BLTW was 1.39 and 1.64 times respectively when compared to a control beam BLSW strengthened with single layer of EB GFRP. And, the corresponding positive changes in ultimate deflection were 2.53 and 7.62 times in beam BLDW and BLTW respectively to that of control beam BLSW.

6.9. The mode of failure of beam remains same for beams strengthened with externally bonded glass fiber reinforced polymer (GFRP) wraps at ultimate load. But, a marginal increase in the load carrying capacity is observed when a beam was strengthened using externally bonded GFRP wraps.

6.10. A relative increase in deflection is also observed for the beams when strengthened with EB GFRP which indicates the flexural behavior of beam before failure.

6.11. The GFRP wraps were failed at the beam corners due to stress concentration.

6.12. The de-bonding of the externally bonded GFRP wraps was observed only where the failure had taken place. Else the GFRP wrap was observed to be bonded to the beam surface firmly.

So, the summary of all the conclusions leads to the final outcome as, the composite action of beam and GFRP had resulted in a noticeable change with respect to enhancement in the shear capacity of the beam and the experimental study with regards to concluded result found satisfactory.

\section{Acknowledgement}

The authors wish to express their gratitude and sincere appreciation to the Prof. Dr. P. B. Murnal, Head of Applied Mechanics Department and Principal for his encouragement, guidance and allowing us to use the all facilities in the department.

\section{References}

[1]. Ghogare, V. P.; and Varma, M. B., "Near Surface Mounted GFRP Strips: An Overview", International Journal for Scientific Research \& Development (IJSRD), Volume-03, Issue-06, June 2015, pp.662-666.

[2]. Murali, G.; and Pannirselvam, N., "Flexural Strengthening of Reinforced Concrete Beams using Fiber Reinforced Polymer Laminate: A Review", ARPN Journal of Engineering and Applied Sciences, Volume 06, Issue 11, Nov 2011, pp.41-47.

[3]. Saafan, M. A. A., "Shear Strengthening of Reinforced Concrete Beams using GFRP Wraps", Czech Technical University in Prague, Acta Polytechnica Volume-46 N0. 1/2006, pp.24-32.

[4]. Sawant, S. G.; Sawant, A. B.; and Kumthekar, M. B., "Strengthening of R.C.C. Beam- using Glass Fibre", International Journal of Inventive Engineering and Sciences (IJIES), Volume-1, Issue-2, January 2013, pp.01-08.

[5]. Satpute A. S.; and Varma M. B., "Retrofitting of Concrete Beams Using Externally Bonded GFRP Wraps- an Overview", International Journal for Scientific Research \& Development (IJSRD), Volume-03, Issue-12, 2016, pp.720-723.

[6]. Banthia, N., "Fiber Reinforced Polymers in Concrete Construction and Advanced Repair Technologies", Professor and distinguished University Scholar, Department of Civil Engineering, University of British Columbia, 2324 Main Mall, Vancouver, BC, Canada, V6T 1 Z4 